\title{
MICROBIOLOGICAL AND PHYSICOCHEMICAL QUALITY OF CURD CHEESE SOLD IN THE STATE OF ALAGOAS (BRAZIL)
}

\author{
KARLA DANIELLE ALMEIDA SOARES* \\ AYODHYA CARDOSO RAMALHO** \\ SILVANA MAGALHÃES SALGADO*** \\ ALDA VERÔNICA SOUZA LIVERA**** \\ RINALDO APARECIDO MOTA*****

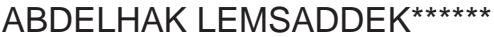 \\ TERESA SEMEDO LEMSADDEK ${ }^{\star * \star * \star * *}$ \\ ELIZABETH SAMPAIO DE MEDEIROS ${ }^{\star \star \star \star * \star \star *}$
}

\begin{abstract}
The present study aimed to evaluate the microbiological and physicochemical quality of curd cheese commercialized in Alagoas (BRAZIL). Thirty samples were collect during a five months period in six points of sale. It was estimated the number of coagulase-positive Staphylococcus and coliforms, as well as the presence of Salmonella spp. and Listeria monocytogenes. Regarding physicochemical characteristics, $\mathrm{pH}$, fat content and humidity were evaluated. Among the thirty analyzed samples, $20(66.6 \%)$ were in accordance with Brazilian legislation parameters for coliforms, while 10 (33.3\%) surpassed those limits. For coagulase-positive Staphylococcus 15 samples (50\%) showed values above the allowed by legislation. None of the samples analyzed harbored Salmonella spp. or Listeria monocytogenes. Regarding physicochemical parameters, the average values observed were of 5.89 for $\mathrm{pH}, 23.6 \%$ for fat content and $46.96 \mathrm{~g} / 100 \mathrm{~g}$ for humidity. Overall, the results obtained reflect the poor hygienic conditions observed from manufacture to commercialization, pointing towards a potential health risk for curd cheese consumers. Furthermore is necessary to regulate physicochemical standards for curd cheese fabication.
\end{abstract}

* $\quad$ Médica Veterinária, Mestranda em Nutrição, Professora Auxiliar, Universidade Federal de Alagoas (UFAL), Campus Arapiraca, Unidade Educacional Viçosa, Fazenda São Luis, Viçosa, AL (e-mail: karlla.vet@hotmail.com).

** Médica Veterinária, Residente na área de Patologia Clínica, Hospital Veterinário, Universidade Federal Rural de Pernambuco, (UFRPE) Recife, PE (e-mail: ayodhya_sol@hotmail.com).

*** Nutricionista, Doutora em Nutrição, Professora Adjunta, Departamento de Nutrição, Centro de Ciências da Saúde, Universidade Federal de Pernambuco (UFPE), Recife, PE (e-mail: silvanasalgado@ufpe.br).

**** Nutricionista, Doutora em Bioquímica, Professora Adjunta, Departamento de Nutrição, Centro de Ciências da Saúde, UFPE, Recife, PE (e-mail: aldalivera@ufpe.br).

***** Médico Veterinário, Pós-doutorado em Doenças Parasitárias de Ruminantes, Professor Associado III, Departamento de Medicina Veterinária, UFRPE, Recife, PE (e-mail: rinaldo.mota@hotmail.com).

******Biólogo, Faculdade de Ciências, Centro de Biodiversidade, Genómica Integrativa e Funcional (BioFIG), Universidade de Lisboa, Campo Grande, Lisboa, Portugal - e-mail (e-mail: alemsaddek@fc.ul.pt).

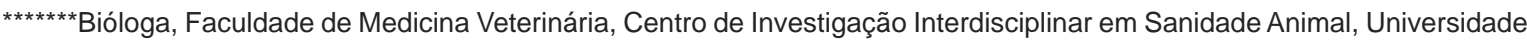
Técnica de Lisboa, Lisboa, Portugal (e-mail: tlemsaddek@fmv.utl.pt).

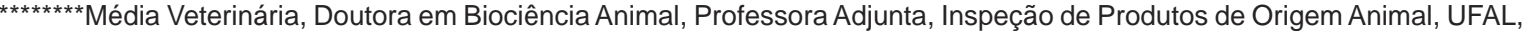
Campus Arapiraca, Unidade Educacional Viçosa, Viçosa, AL (e-mail: sampaio.elizabeth@gmail.com). 


\section{INTRODUCTION}

Curd cheese, an artisanal product from the northeast region of Brazil, is very popular, has an important impact on the economy of small/mid-size farmers and constitutes a work source for the region (NASSU et al., 2003; GUEDES NETO et al., 2004; TESHIMA et al., 2004).

Among milk derived products, cheese stands out for its high protein content and presence of other nutrients (BORGES et al., 2003). However, it is considered a frequent vehicle of foodborne pathogens, especially soft cheese, for being frequently produced from raw milk and holding no maturation process during its manufacture. Microbiological contamination, and ultimately foodborne diseases, are of major importance for the cheese industries, due not only to financial losses, but also because of the concerns regarding public health (FEITOSA, 2003).

Several studies showed the presence of pathogenic microorganisms in curd cheese and estimation of deteriorative microbes levels exceeding the Brazilian law limits. Among these bacteria Salmonella spp., Escherichia coli and Staphylococcus aureus were emphasized (CAVALCANTE et al., 2007).

The high number of coliforms, which is frequently observed in curd cheese, suggests poor hygiene conditions during manufacture. Additionally, the presence of thermotolerant coliforms points towards a direct contact with fecal material (DUARTE et al., 2005). These observations point at the quality control of milk and dairy-derived products as fundamental factor to ensure public health. Quality parameters may include physical, chemical, microbiological and sensitive determinations, as well as hygiene tests. Chemical composition must be analyzed considering the minimal patterns demanded by the Ministry of Agriculture, Cattle and Development (VENTUROSO, 2007).

The present study aims to evaluate the microbial and physicochemical quality of curd cheese commercialized in the state of Alagoas (BRAZIL).

\section{MATERIAL AND METHODS}

\subsection{SAMPLES}

Thirty samples of curd cheese previously submitted to inspection, were randomly collected from six commercial establishments in the state of Alagoas, between August and December 2011. The samples came from the cities of Viçosa, Maceió, Quebrangulo, Capela, Arapiraca and Major Isidoro. Samples were collected in sterile bags and transported to the Laboratory of Food Analysis and Experimentation of the Universidade Federal de Pernambuco using isothermal boxes. After external cleaning the collecting bags using $70 \%$ ethanol, the cheese-samples were processed in a laminar flow chamber, as recommended by Silva, Junqueira \& Silveira (2001).

\subsection{MICROBIAL ANALYSIS}

Quantitative estimation of thermotolerant coliforms and coagulase positive staphylococci were carried out, as well as screening for the presence of Salmonella sp. and Listeria monocytogenes. For quantitative determination of coagulase positive Staphylococcus, $25 \pm 0.2 \mathrm{~g}$ of curd cheese were homogenized with buffered peptone water $(0.1 \%)$ and diluted in a series of dilution tubes to the $10^{-3}$, according to Silva, Junqueira \& Silveira (2001). For coliforms counting the most probable number method (MPN) was applied, while the presence of Salmonella spp. and Listeria monocytogenes were determined as recommended by Silva et al. (2007).

\subsection{PHYSICOCHEMICAL ANALYSIS}

Estimation of $\mathrm{pH}$ values, fat content and humidity were performed as recommended by the Instituto Adolfo Lutz analytical norms (2008). 


\section{RESULTS AND DISCUSSION}

\subsection{MICROBIAL ANALYSIS}

Regarding thermotolerant coliforms (Table 1), 10 (33.3\%) of the 30 samples were in disagreement with the microbiological standards of the RDC 12 (BRASIL, 2001). For the remaining

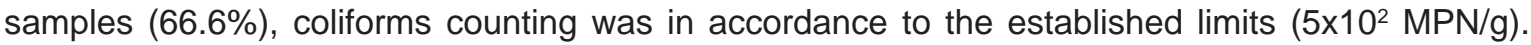
These results do not agree with those of Santana et al. (2008). Those authors analyzed 60 samples of curd cheese collected in Aracaju (SE) and their results for thermotolerant coliforms showed that 93.3\% of the samples were unfit for commercialization, and therefore for human consumption. It is important to highlight that thermotolerant coliforms are members of the human/animal intestinal microbiota and their presence in food products points toward a direct and/or indirect contact between the product and fecal matter. In addition, the water used in the production of cheese is not undergoing through any kind of treatment, wich may be an important source of food contamination. Due to the known pathogenicity of this group of microorganisms, their presence in foodstuffs constitutes a risk for consumers' health (SALOTTI et al., 2006).

TABLE 1 - MICROBIAL RESULTS OF THE ALAGOAS CURD CHEESE AND
RDC 12 STANDARDS (BRASIL, 2001)

\begin{tabular}{c|l|l|l|l}
\hline \multirow{2}{*}{ Microorganism } & Counting & $\mathbf{N}^{\circ}$ samples & $\mathbf{( \% )}$ & $\begin{array}{l}\text { RDC 12 } \\
\text { standard }\end{array}$ \\
\hline \multirow{2}{*}{ Fecal Colirforms (MPN/g) } & $<3$ & 5 & 16.6 & \multirow{2}{*}{$5 \times 10^{2}$} \\
\cline { 2 - 5 } & $15-240$ & 15 & 50 & \\
\cline { 2 - 5 } & $>1100$ & 10 & 33.3 & \multirow{2}{*}{$5 \times 10^{2}$} \\
\hline $\begin{array}{c}\text { Staphylococcus (UFC/g) } \\
\text { Salmonella sp. (in 25 g) }\end{array}$ & $3.4 \times 10^{4}$ & 5 & 16.6 & \\
\cline { 2 - 5 } & $>3.4 \times 10^{4}$ & 10 & 33.3 & Absent \\
\hline \multirow{2}{*}{ Listeria monocytogenes(in 25 g) } & Absent & 30 & 100 & Absent \\
\hline
\end{tabular}

The presence of coagulase positive Staphylococcus was confirmed for 15 samples (50\%), with a number of colonies higher than $3.4 \times 10^{4} \mathrm{CFU} / \mathrm{g}$, which is beyond the limits of RDC 12 (BRASIL, 2001). Oliveira and coworkers (2010) analyzed 42 samples of cured cheese in the city of Cabo de Santo Agostinho, Pernambuco. Their results showed that coagulase positive Staphylococcus were present in $76.19 \%$, with colony numbers between $1.6 \times 10^{3}$ and $2 \times 10^{5} \mathrm{CFU} / \mathrm{g}$, which is also higher that

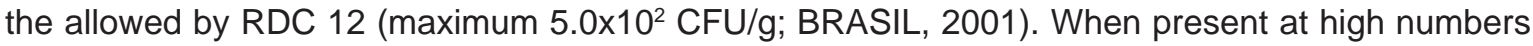
$\left(10^{5}-10^{6} \mathrm{CFU} / \mathrm{g}\right.$ or $\mathrm{mL}$ ) and under suitable conditions (temperature, $\mathrm{pH}, \mathrm{a}_{\mathrm{w}}$ and $\left.\mathrm{O}_{2}\right)$, coagulase positive Staphylococcus may produce one, or several, enterotoxins in the food matrix, which may cause intoxication, thus constituting an important risk for consumers' health (BORGES, 2008).

None of the samples harbored Salmonella or L. monocytogenes, in agreement with standards established by ANVISA (BRASIL, 2001) which preconizes their absence in $25 \mathrm{~g}$ of cheese. Borges et al. (2003) analyzed 11 samples of curd cheese in the state of Rio Grande do Norte and $L$. monocytogenes was absent. Santana and coworkers (2008) detected the presence of Salmonella spp. in $26.7 \%$ of the 60 commercially available curd cheese samples from Aracaju. 
Average values obtained for the physicochemical analysis of curd cheese are presented in Table 2.

\section{TABLE 2 - PHYSICOCHEMICAL ANALYSIS OF CURD CHEESE COMMERCIALIZED IN ALAGOAS}

\begin{tabular}{l|l|l|l}
\hline Parameter & Minimum & Maximum & Average \\
\hline Fat (\%) & 20 & 26 & 23.6 \\
\hline $\mathrm{pH}$ & 5.43 & $6 . .25$ & 5.89 \\
\hline Humidity g/100 g & 42.1 & 50.41 & 46.96 \\
\hline
\end{tabular}

Fat content in the analyzed curd cheeses varied between 20 and $26 \%$, which agrees with the results of Freitas Filho et al. (2009). These authors studied fat content of curd cheese in Jucati (PE) having found levels between 18.99 and $31.88 \%$.

Hydrogenionic concentration, which determines the $\mathrm{pH}$ of the food product, is one of the main factors that exert influence on microbial growth, survival or elimination within the food matrix (SILVA, 2000). Average $\mathrm{pH}$ of the samples in this study was 5.89 , which is higher than the reported by Machado et al. (2004) in minas cheese ( $\mathrm{pH} 4.98)$.

Humidity content of the samples under analysis varied between 42.1 and $50.41 \%$. According to Technical Regulation of Identity and Quality of cheese, curd cheese can be classified as presenting middle ( 36.0 to $45.9 \%$ ) to high humidity ( 46 to $55 \%$ ). The results confirmed those observed by Silva et al. (2010) that found humidity contents between 45.5 and $51.5 \%$ in milk products from Hinterland of Alagoas.

Overall, it is important to determine the physicochemical parameters of the products before commercialization in order to screen for fraudulent products and attribute an accurate commercial value to each foodstuff (AGNESE et al., 2002). Additionally, this study emphasizes the need for a legislation that standardizes the physicochemical parameters to be controlled during cheese manufacture.

\section{CONCLUSION}

The present study demonstrates that the hygienic conditions observed during manufacturing and/or commercialization of curd cheese influence the microbiological quality of the product. Although physicochemical parameters were in accordance to the results found in similar regional studies, coagulase positive Staphylococcus and thermotolerant coliforms were detected at numbers over the limits established by Brazilian legislation pointig the consumption of curd cheese as a health risk, especially for consumers with an impaired immune system.

\section{RESUMO}

\section{QUALIDADE MICROBIOLÓGICA E FÍSICO-QUÍMICA DO QUEIJO DE COALHO COMERCIALIZADO NO ESTADO DE ALAGOAS (BRASIL)}

Objetivou-se com este estudo verificar a qualidade microbiológica e físico-química do queijo de coalho comercializado em Alagoas. Foram avaliados 6 pontos de venda, durante cinco meses, totalizando 30 
amostras analisadas. Efetuou-se a contagem de Staphylococcus coagulase positiva (SCP) e de coliformes termotolerantes, assim como a pesquisa de Salmonella spp. e Listeria monocytogenes. As amostras foram submetidas às análises de pH, teor de gordura e umidade. Das 30 (100\%) amostras estudadas, 20 (66,6\%) estavam em conformidade com a legislação brasileira quanto à presença de coliformes termotolerantes e 10 $(33,3 \%)$ encontravam-se acima do limite tolerado pela legislação. Foram encontrados Staphylococcus coagulase positiva em 15 amostras com valores acima do permitido pela legislação. Não foi observada a presença de Salmonella sp. e Listeria monocytogenes. Nas análises físico-químicas, os valores médios encontrados foram: gordura - 23,6\%; umidade - 46,96 g/100 g; pH-5,89. Conclui-se que o perfil microbiológico do queijo reflete as más condições higiênicas de fabricação e comercialização do produto, oferecendo riscos aos consumidores. Além disso, existe a necessidade de regulamentação dos padrões físico-químicos para fabricação do queijo de coalho.

PALAVRAS-CHAVE: QUEIJO ARTESANAL; QUEIJO - QUALIDADE MICROBIOLÓGICA; QUEIJO QUALIDADE FÍSICO QUÍMICA; RISCO PARA SAÚDE.

\section{REFERENCES}

1 AGNESE, A.P.; NASCIMENTO, A.M.D. do; VEIGA, F.H.A.; PEREIRA, B.M.; OLIVEIRA, V.M. de. Avaliação físicoquímica do leite cru comercializado informalmente no Município de Seropédica - RJ. Revista Higiene Alimentar, v.16, n. 94. p. $58-61,2002$.

2 BORGES, M.F.; FEITOSA, T.; NASSU, R.T.; MUNIZ, C.R.; AZEVEDO, E.H.F.; FIGUEIREDO, E.A.T. Microrganismos patogênicos e indicadores em queijo de coalho produzido no Estado do Ceará, Brasil. Boletim do CEPPA, v.21, n.1, p.31-40, 2003.

3 BORGES, M.F.; NASS, R.T.; PEREIRA, J.L.; ANDRADE, A.P.C.; KUAYE, A.Y. Perfil de contaminação por Staphylococcus e suas enterotoxinas e monitorização das condições de higiene em uma linha de produção de queijo. Ciência Rural, Santa Maria, v.38, n.5, p. 1431-1438, 2008.

4 BRASIL. Ministério da Saúde. RDC n. 12, de janeiro de 2001. Aprova o regulamento técnico sobre padrões microbiológicos para alimentos. Diário Oficial [da] República Federativa do Brasil, Poder Executivo, 10/01/2001, Brasília, 2001. Art. 4a, p. 1-48. Available on: http://portal.anvisa.gov.br/wps/wcm/connect/a47bab8047458b909541d53fbc4c6735/ RDC_12_2001.pdf?MOD=AJPERES. Accessed at: Mar. 28, 2012.

5 CAVALCANTE, J.F.M.; ANDRADE, N.J.; FURTADO, M.M. et al. Processamento do queijo de coalho regional empregando leite pasteurizado e cultura lática endógena. Cienc.Tecnol. Aliment., v.27, p.205-214, 2007.

6 DUARTE, D.A.M.; SCHUCH, D.M.T.; SANTOS, S.B. et al. Pesquisa de Listeria monocytogenes e microrganismos indicadores higiênico-sanitários em queijo-coalho produzido e comercializado no estado de Pernambuco. Arq. Inst. Biol., v.72, p.297-302, 2005.

7 FEITOSA, T.; BORGES, M.F.; NASSU, R.T.; AZEVEDO, E.H.F.; MUNIZ, C.R. Pesquisa de Salmonellasp., Listeria sp. e microrganismos indicadores higiênico-sanitários em queijos produzidos no estado do Rio Grande do Norte. Ciência e Tecnologia de Alimentos, Campinas, v. 23, supl., p. 162-165, dez. 2003.

8 FREITAS FILHO, J.R.; SOUZAFILHO, J.S.; OLIVEIRA, H.B.; ANGELO, J.H.B. BEZERRA, J.D.C.B. Avaliação da qualidade do queijo "coalho" artesanal fabricado em Jucati-PE. Revista Eletrônica de Extensão, v.6, n.8, 2009. Available on: http:// www.periodicos.ufsc.br/index.php/extensio/article/download/11393/11446. Accessed at: Mar. 28, 2012.

9 INSTITUTO ADOLFO LUTZ. Normas analíticas do Instituto Adolfo Lutz: métodos físico-químicos para análise de alimentos. 4. ed. Brasília, ANVISA, 2008.

10 MACHADO, E.C.; FERREIRA C.L.L.F.; FONSECA, L.M.; SOARES, F.M.; JÚNIOR, F.N.P. Características físico-químicas e sensoriais do queijo minas artesanal produzido na região do Serro, Minas Gerais. Ciência e Tecnologia de Alimentos, Campinas, v.24, n. 4, p. 516-521, out.-dez. 2004.

11 NASSU, R.T. et al. Diagnóstico das condições de processamento e caracterização físico-química de queijos regionais e manteiga no Rio Grande do Norte. Fortaleza: Embrapa Agroindústria Tropical, 2003.

12 GUEDES NETO, L.G.; NEVES, M.V.O.; VELOSO, F.P.; PAIVA, R.M.B.; PENNA, C.F.A.M.; SENNA, M.J. Qualidade físicoquímica e microbiológica de queijo de coalho produzido no Brasil - revisão. Revista do Instituto de Laticínios Cândido Tostes, Juiz de Fora, v. 59, n. 339, p. 236-239, 2004.

13 OLIVEIRA, K.A. de; NETO, J.E.; PAIVA, J.E. de; MELO, L.E.H. Qualidade microbiológica do queijo de coalho comercializado no Município de Cabo de Santo Agostinho, Pernambuco, Brasil. Arq. Inst. Biol., São Paulo, v.77, n.3, p.435-440, 2010.

14 SALOTTI, B.M.; CARVALHO, A.C.F.B.; AMARAL, L.A. et al. Qualidade microbiológica do queijo minas frescal comercializado no município de Jaboticaba, SP, Brasil. Arq. Inst. Biol., v.73, p. 171-175, 2006. 
15 SANTANA, R.F.; SANTOS, D.M.; MARTINEZ,A.C.C.; LIMA, A.S. Qualidade microbiológica de queijo-coalho comercializado em Aracaju, SE. Arquivo Brasileiro de Medicina Veterinária e Zootecnia, v.60, n.6, p.1517-1522, 2008.

16 SILVA, J.A. Tópicos da tecnologia de alimentos. São Paulo: Varela, 2000. 231 p.

17 SILVA, N.; JUNQUEIRA, V.C.A.; SILVEIRA, N.F.A Manual de métodos de análises microbiológicas de alimentos. São Paulo: Livraria Varela, 2001. 317 p.

18 SILVA, N. da; JUNQUEIRA, V.C.A.; SILVEIRA, N.F.A.; TANIWAKI, M.H.; SANTOS, R.F.S. dos; GOMES, R.A.R. Manual de métodos de análise microbiológica de alimentos. 3. ed. São Paulo: Livraria Varela, 2007. 552 p.

19 SILVA, M.C.D. da; RAMOS, A.C.S.; MORENO, I.; MORAES, J.O. Influência dos procedimentos de fabricacão nas características fisico-quimicas, sensoriais e microbiológicas de queijo de coalho. Revista Instituto Adolfo Lutz, v.69, n.2, p. 214-221, 2010 .

20 TESHIMA, E.; VIANA, A.C.; DE ASSIS, M.M.S.; FIGUEIREDO, H.M. Identidade e qualidade do queijo de coalho comercializado em Feira de Santana-BA. Revista do Instituto de Laticínios Cândido Tostes, Juiz de Fora, v. 59, n. 339, p. 194-197, jul./ago. 2004.

21 VENTUROSO, R.C.; ALMEIDA, K.E.; RODRIGUES, A.M.; DAMIN, M.R.; OLIVEIRA, M.N. Determinação da composição físico-química de produtos lácteos: estudo exploratório de comparação dos resultados obtidos por metodologia oficial e por ultra-som. Revista Brasileira de Ciências Farmacêuticas, São Paulo, v. 43, n. 4, p. 607-613, 2007. 